\title{
The age of deposition of accumulative fan sediments in Serteyka River Valley (Western Russia)
}

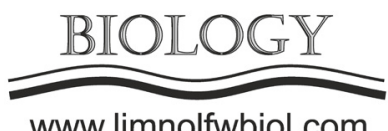

\author{
Ginter A. ${ }^{1 *}$, Piech W. ${ }^{2}$, Krąpiec M. ${ }^{3}$, Moska P. ${ }^{4}$, Sikorski J. ${ }^{5}$, Hrynowiecka A. ${ }^{6}$, \\ Stachowicz-Rybka R. ${ }^{7}$, Mroczkowska A. ${ }^{2,8}$, Mazurkevich A. ${ }^{9}$, Kittel P. ${ }^{2}$
}

\footnotetext{
${ }^{1}$ University of Lodz, Faculty of Philosophy and History, Institute of Archaeology, Laboratory of Spectrometry and Thermoluminescence Dating, Lodz, Poland

${ }^{2}$ University of Lodz, Faculty of Geographical Sciences, Department of Geomorphology and Palaeogeography, Lodz, Poland

${ }^{3}$ AGH - University of Science and Technology, Faculty of Geology, Geophysics and Environmental Protection, Krakow, Poland

${ }^{4}$ Institute of Physics, Silesian University of Technology, Gliwice, Poland

${ }^{5}$ Institute of Physics Centre for Science and Education Department of Radioisotopes GADAM Centre of Excellence, Silesian University of Technology, Gliwice, Poland

${ }^{6}$ Gdansk Polish Geological Institute - National Research Institute, Marine Geology Branch, Gdansk, Poland

${ }^{7}$ W. Szafer Institute of Botany Polish Academy of Sciences, Krakow, Poland

${ }^{8}$ Polish Academy of Sciences, Institute of Geography and Spatial Organization, Past Landscape Dynamics Laboratory, Warsaw, Poland

${ }^{9}$ The State Hermitage Museum, St. Petersburg, Russia
}

\begin{abstract}
In the region of the Serteyka River, an extensive accumulative fan was studied. The main goal of the research is an attempt to reconstruct the palaeogeographic development of erosive cuts in Western Russia. The geological structure of the fan and its surroundings was recognized. The fan is built by deluvium sediments, which can be divided into: lower diluvium unit, middle diluvium unit and upper diluvium unit. The top of the fan is built by tillage diamicton. The fan was formed at the earliest from the 2nd half of the 17th century (during the Little Ice Age pessimum). Samples were taken for AMS, OSL, $\mathrm{Pb}^{210}$ dating to determine the phases of fan's development. The AMS dating produced mixed results. This was due to the redeposition of the material. Using the OSL method, two samples were dated from the bottom of the clastic fan deposits. Dates from the Neolithic period were obtained, additionally in inversion. It was caused by inaccurate bleaching of the quartz grains. The top part of the fan was dated using the $\mathrm{Pb}^{210}$ method. Slope sediments can be extremely difficult to dating. This may be due to the redeposition of the material, the presence of hiatuses and inaccurate bleaching of samples. The individual units of deluvium sediments differ in colour, structural and textural features.
\end{abstract}

Keywords: Geochronology, Little Ice Age, Human impact, Agrotechnical activity, Hillslope processes

\section{Introduction}

The studied area is located in the East European Plain in Western Russia, on the border of the Pskov, Tversk and Smolensk Oblasts. The Serteya region lies within the Vitebsk Lakeland after Kondracki (1992) or in the Western Dvina Lakeland after Abramov (1972). The investigated accumulative fan was formed in the mouth of a well-developed system of erosion cuts in the Lower Serteyka River Valley.

Carrying out study of erosional cuts and accumulative fans was to include revise the hypothesis that the activity of Neolithic cultures shaped the slopes of the Serteyka River Valley. Due to the fact that a number of archaeological sites were discovered there and dated from the late Paleolithic to the Modern Period, mostly however to the Neolithic (e.g. Mazurkievich et al., 2009a, 2009b; Mazurkevich and Dolbunova, 2015; Kul'kova et al., 2015; Mazurkevich et al., 2017; Kittel et al., 2018). First results of geochronometric analysis have demonstrated that the largest erosional cuts system were developed at the earliest since the $2^{\text {nd }}$ half of the $17^{\text {th }}$ cent. AD (Piech et al., 2018). It shows a very rapid rate of development of these forms occurred during the pessimum of the Little Ice Age (LIA) and the period of increasing human impact, associated with the agricultural, as well as industrial revolution.

\section{Materials and methods}

The gully system vicinity, as well as the accumulative fan has been geologically recognized by a dense network of hand augering. Geological outcrops were also made in the wall and bottom of one of the

*Corresponding author.

E-mail address: artur.ginter@uni.lodz.pl (A. Ginter)

(C) Author(s) 2020. This work is distributed under the Creative Commons Attribution 4.0 License. 
gully and in central and distal zone of the fan.

Geochemical analysis was performed for fan's sediments using XRF method, $\mathrm{pH}$, electrolytic conductivity and calcium carbonate content using Scheilber's method.

Selected plant macro-remains (charcoal, needles and seeds) were separated from individual layers of clastic fan deposits for radiocarbon dating using the AMS method. Considering the risk of dating macroscopic plant remains from the deluvium, it was decided to perform OSL and ${ }^{210} \mathrm{~Pb}$ dating to thoroughly analyze the stages of fan formation. Samples for OSL dating were taken at night under filtered, red light. Two OSL dates have been obtained from the fan bottom part.

\section{Results and discussion}

The Serteyka River valley slopes are strongly inclined in the analyzed area from $20^{\circ}$ to $52^{\circ}$.The largest gully is cut to a length of about $210 \mathrm{~m}$ into the glaciofluvial plain. This gully has two main branches: the first runs latitudinally and is ended with the mouth of the entire gully system, the second runs meridionally joining the latitudinal branch in their central fragment. The maximum depth of the form is about $7 \mathrm{~m}$ and the width the mouth is about $15 \mathrm{~m}$.

The accumulative fan is built by deluwia, proluvia and tillage diamicton (Piech et al., 2018). Due to structural and textural features, deluvium can be divided into: lower deluvium unit with intersections of the proluvium, middle deluvium unit and upper deluvium unit. The lower deluvium unit is characterized by very weak lamination and light brown yellow colour, the middle diluvium unit has a brown colour and the textual indicators are similar. Subhorizontal stratification is significant for the upper deluvium unit. This layer is characterized also by fluctuations in the value of sedimentological indicators: mean grain-size, sorting index, skewness and kurtosis. The sedimentological and geochemical traits of the distinguished deluvium units differ significantly, which indicates the changing environmental conditions prevailing during their accumulation.

Moreover, the volume of eroded sediments in the largest gully system was estimated to $3883.2 \mathrm{~m}^{3}$, while the volume of the accumulative fan formed at its mouth is $3639.6 \mathrm{~m}^{3}$. The volume difference ( 243.4 $\mathrm{m}^{3}$ ) indicates the only small amount of slope deposits were incorporated into the fluvial system or eroded by Aeolian processes.

An important task of our study is to specify in detail the chronology of the formation and development of the studied accumulative fan, which will allow for linking these processes with palaeoenvironmental events that have had an impact on the intensification of erosion and accumulation. We cannot rely solely on only one type chronological data set. For this reason, we are trying to elaborate the chronological model of the accumulative fan development based on: radiocarbon $\left({ }^{14} \mathrm{C}\right)$, optically stimulated luminescence (OSL) and lead $\left({ }^{210} \mathrm{~Pb}\right)$ dating.
In several places it was noted that the upper (younger) layers have achieved several hundred years older dates than the lower ones (older). It is the result of the redeposition sediments or macro-remains. In the studied case, a positive feature is that the fan clastic sediments were deposited directly on biogenic lacustrine/peat deposits. Unfortunately, these biogenic sediments could be also partly redeposited due to floods or slope processes. The acquired age far exceeded our expectations. The dates obtained indicate the Neolithic period, where the ceiling of biogenic sediments is dated to the $2^{\text {nd }}$ half of the $17^{\text {th }}$ century $\mathrm{AD}$. In addition, a chronological inversion of OSL dates occurs. This may be due to inaccurate bleaching of the grains during slope transportation processes, which indicates that the material being transported had a relatively large volume. This further indicates not slope wash, but rather the drainage of fluidized sediment flow (mudflows).

The investigated profile results of measurements values of the allochthonous ${ }^{210} \mathrm{~Pb}$ activity versus depth for measured core show the decrease of ${ }^{210} \mathrm{~Pb}$ with depth, which should be expected for modern sediments. It demonstrates also that studied slope sediments of the accumulative fan have been deposited before ca. 1850 AD.

\section{Conclusions}

Palaeobotanical, palaeozoological and geochemical analysis of biogenic deposits revealed the stages of lake level fluctuations, wetland development, local floods, as well as most likely the initiation of slope erosion due to human impact. There were favorable conditions for the emergence and development of extensive erosive cuts systems in the study area: deforestation caused by human, intense agrotechnical activity, increased rainfall during the Little Ice Age and favorable geomorphological, geological and topographic conditions of a strongly inclined slope. The above conditions were suitable for intense formation processes of gullies system and a large accumulative fan, with a maximum thickness of sediments reaching about $2 \mathrm{~m}$ accumulated during ca. 200 years (from mid$17^{\text {th }}$ to mid- $19^{\text {th }}$ cent. AD).

Slope sediment geoarchive and biogenic bioarchive underlying slope sediments are an almost continuous record of the evolution of the environment, which was mainly influenced by climate change and human impact in Middle Ages and Modern Period.

\section{Acknowledgements}

The research project has been financed by grant from The National Science Center in Poland (nr 2019/03/X/HS3/02019)

\section{References}

Abramov LS 1972. Opisaniya prirody nashey strany: Razvitiye fiziko-geograficheskikh kharakteristik. Mysl'. Moskva. (in Russian) 
Kittel P, Mazurkevich A, Dolbunova E, Kazakov E, Mroczkowska A, Pavlovskaia E, Piech W, Płóciennik M, Sikora J, Teltevskaya Y, Wieckowska-Lüth M 2018. Palaeoenvironmental reconstructions for the Neolithic piledwelling Serteya II site case study, Western Russia. Acta Geographica Lodziensia 107: 191-213.

Kondracki J 1992. Physico-geographic regionalization of the Lithuanian and Belarusian republics in a decimal system. Przegląd Geograficzny (Geographic Overview) 64(3-4): 341-346. (in Polish)

Kul'kova MA, Mazurkevich A, Gerasimov D 2015. Stone Age archaeological sites and environmental changes during the Holocene in the NW region of Russia. In: Harff, J., Bailey, G., Lüth, F. (Eds.), Geology and Archaeology: Submerged Landscapes of the Continental Shelf. Geological Society, London: 27-50.

Mazurkevich, AN, Korotkevich BN, Dolukhanov, PM, Shukurov AM, Arslanov KhA, Savel'eva LA, Dzinoridze, EN, Kulkova MA, Zaitseva GI 2009a. Climate, subsistence and human movements in the Western Dvina - Lovat River Basins. Quaternary International 203 (1-2): 52-66.

Mazurkevich, A, Hookk D, Fassbinde, J 2009b.
Magnetometry and susceptibility prospection on neolithicearly Iron Age sites at Sertey, North-Western Russia. ArcheoSciences Revue d'archeometrie, supplement 33: 81-85.

Mazurkevich A, Dolbunova E 2015. The oldest pottery in hunter-gatherer communities and models of Neolithisation of Eastern Europe. Documenta Praehistorica 42: 13-66.

Mazurkevich A, Dolbunova E, Kittel P, Fassbender J, Maigrot Y, Mroczkowska A, Płóciennik M, Sikora J, Słowiński M, Sablin M, Shirobokov I 2017. Multi-disciplinary research on the Neolithic pile-dwelling Serteya II site (Western Russia) and the landscape reconstruction. In: MarciniakKajzer, A., Andrzejewski, A., Golański, A., Rzepecki, S. (Eds.), Nie tylko krzemienie. Not only flints. Instytut Archeologii Uniwersytetu Łódzkiego, Łódzka Fundacja Badań Naukowych, Stowarzyszenie Naukowe Archeologów Polskich Oddział w Łodzi. Łódź: 103-128.

Piech W, Kittel P, Mazurkevich A, Pavlovskaia E, Kazakov E, Teltevskaya Y, Błaszczyk K, Kotrys B 2018. Sedimentological features and depositional conditions of deposits of the accumulative fan in the Serteyka River valley (Western Russia). Acta Geographica Lodziensia 107: 215-238. (in Polish) 